\title{
Do Brand Extensions Affect Consumer Attitude: An Empirical Experience-With Reference To Pakistani Consumers
}

Zain-Ul-Abideen, Islamia University of Bahawalpur, Pakistan Abdul Latif, Islamia University of Bahawalpur, Pakistan

\begin{abstract}
This study examines consumer attitude and empirically test the factors that differentiate between successful and unsuccessful brand extensions, on the basis of parent brand attributes and characteristics, in reference to variables such as brand similarity, brand reputation, multiple brand extension, parent brand characteristics and brand concept consistency using actual extensions of two brands i.e. Olpers Cream (extension of Olpers Milk) and Lipton tea bag (extension of Lipton tea). A sample of 430 consumers of Bahawalpur District (Pakistan) was selected for the survey. Stratified proportionate sampling (in proportion to the population of each Union Council) was used for drawing these samples. The study suggests a more prominent role of parent brand attributes and characteristics than brand extension that had been acknowledged in the literature. Further, the study documents the importance of an extension's fit with the parent brand's image while at the same time suggesting that similarity between the brand extension and its core brand has positive effect on extension evaluation. It also shows that as perceived appropriateness between the extension and the core brand decreases, attitude toward the core brand on brand-extension evaluation decreases.
\end{abstract}

Keywords: Advertising; Brand Extension; Parent Brand Characteristics; Consumer Attitude; Pakistan

\section{INTRODUCTION}

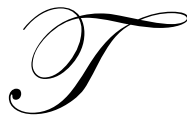

he management of customer churn out is a precedence of management in almost all industries. It is also widely acknowledged acumen in marketing that acquisition of new customer is comparatively more difficult as compared to establishing and strengthening a long-term relationship with established pool of customers. Brand extensions play a vital role in this regard. The use of brand extension that is "using established brand names for launching new products" is increasingly popular as leverage for new product introductions (Volcker and Sattler, 2006). The majority, figures ranging up to 95\% of all new product offerings in the market are some form of extension (Lye et al., 2001), because as the cost of introducing a new product soars and competition intensifies, many firms try to decrease the risks involved in new product introduction, by marketing the new product as a brand extension. Brand extensions also leverage a firm's most valuable hidden asset, brand equity (Tauber, 1981). Line extensions are new (versions of the) products introduced within the same product category, whereas brand extensions are introduced in a different category from the existing business e.g. Diet Coke and Liquid Tide (De Pelsmacker et al., 2007).

Companies widely employ extension strategies because of the belief that these establish and convey strong brand positioning, develop awareness, quality associations and ultimately increase the prospect of trial (Chen and Liu, 2004). When managed well, extensions are great source of income, because it reinforce brand meaning \& quality, therefore help to build strong brand equity (Keller and Sood, 2003). Successful extensions positively influence choice of the parent brand and other extensions (Swaminathan, 2003). There is always a risk involved in extensions even commercially successful extensions, are not always benefit the company as a whole, because sometimes they may cannibalize parent brand sales and image (Völckner et al., 2008). Although benefiting from 
parent brand leverage seems very tempting, but the failure rate of extensions is high and can amount to almost $84 \%$ (Tait, 2001). What is a worse, extension that fails in the market may cause fatal damage to the parent brand as well (Sheinin, 2000).

However, irrespective of these, by introducing new products under well-liked brand names, firms hope that consumers will respond more positively to the new offerings, due to their familiarity with the parent brand, positive attitude toward the parent brand, positive attributes and non-attribute associations they have with the parent brand. What are the factors, which determine whether a brand extension will be successful, or not? The most important factor acknowledged by prior research is perceived fit. Consumers respond more favorably if they are able to perceive a fit between the extended and the core brand (Aaker \& Keller, 1990; Boush et al., 1987). Perceived fit can be based on the extension being in a product category alike to other products sold by the parent brand (Boush et al., 1987; Keller \& Aaker, 1992), complementing use with other products sold by the parent brand (Aaker \& Keller, 1990), being in a product category where the parent brand can contribute an appealing attribute (Broniarczyk \& Alba, 1994; Herr, Farquar, \& Fazio, 1996), having a parent brand with the expertise to make the extension product (Aaker \& Keller, 1990), having a parent brand with an image that is compatible and consistent with the extension (Park et al., 1991).

Indeed, perceived fit is so broadly accepted term that researchers have not considered this possibility that moderating factors may exist which render perceived fit more or less influential in brand extension evaluations (Hakkyun Kim and John, 2008). The working assumption has been that for all types of consumers, perceived fit is always more important for considering brand extensions. So far, the only indication of moderating factors is found in cross-cultural settings, where it has been reported that consumers from eastern cultures put less consideration on perceived fit while evaluating brand extensions, relying in its place more on other factors, such as corporate brand reputation (Bottomley \& Holden, 2001). An important issue in brand extension that many companies are concerned about seems whether, the brand extension designed to attract potential customers, will be received by the parent brand's existing customers in a sound way. Klink (2001) has warned about a limitation in current research on consumer attitudes toward brand extensions, explaining that "In this area, as is often the case during the initial stages of knowledge development, concerns about external validity have taken a back seat to those about internal validity" (Klink \& Smith, 2001).

As, brand extensions are based on the basic assertion that consumers hold positive attitudes toward the parent brand and same can be transferred and applied to extensions. Nevertheless, this is true and valid as long as there is a "fit" between the two i.e. the extension associations are congruent with those of the parent brand (Basu Monga \& Roedder John, 2007). In this paper, we examine how consumer attitude vary toward brand extensions in terms of brand similarity, brand reputation, multiple brand extension, parent brand characteristics and brand concept consistency.

\section{THEORETICAL FRAMEWORK}

Building on the preliminary research by Boush et al., (1987) and Aaker \& Keller (1990), significant progress has been made in the understanding the factors of consumer attitude towards brand extension. While, a thorough study of the literature also suggests that initial research ignores the fact that consumers are heterogeneous and per se, may evaluate brand extensions in dissimilar way as compared to one another. For example, Monga and John (2007) endowed with the evidence that consumers belonging to eastern cultures, characterised by holistic thinking approach, may perceive relatively higher brand extension fit, and evaluate brand extensions more positively and favorably than do western consumers, characterised by analytic thinking approach.

In the current study, "categorization theory" is used as the primary theory to study the brand extension. Categorization theory explains that people faced with an evaluative task first make an effort to classify the object within a certain category based on salient cues (Fiske and Pavelchak, 1986). If the categorization process is successful, then the affect and beliefs associated with this category in memory are transferred to the object itself. Consumers are not only at first confused and disordered in mind, but they also try to categorize the brand association with their existing memory, when thousands of products are faced by them, and they might reposition memories to outline a brand image and perception / concept toward new products. Consumers can evaluate the extended brand 
by their category memory. They can categorize latest information into particular brand or product group label and store them accordingly. This procedure is not only associated to consumer's familiarity and information, but also attachment and preference of brand. If parent brand's association is well related to extended brand, consumer can distinguish the fit among them. It is also suggested that consumer can disregard or prevail over the dissonance from brand extension.

\section{RESEARCH MODEL}

Five variables are used to evaluate consumer attitude toward brand extensions. Research model is adopted from the study conducted by Tariq Jalees and Tahir Ali (2008). A research model showing relationship among variables is depicted here:

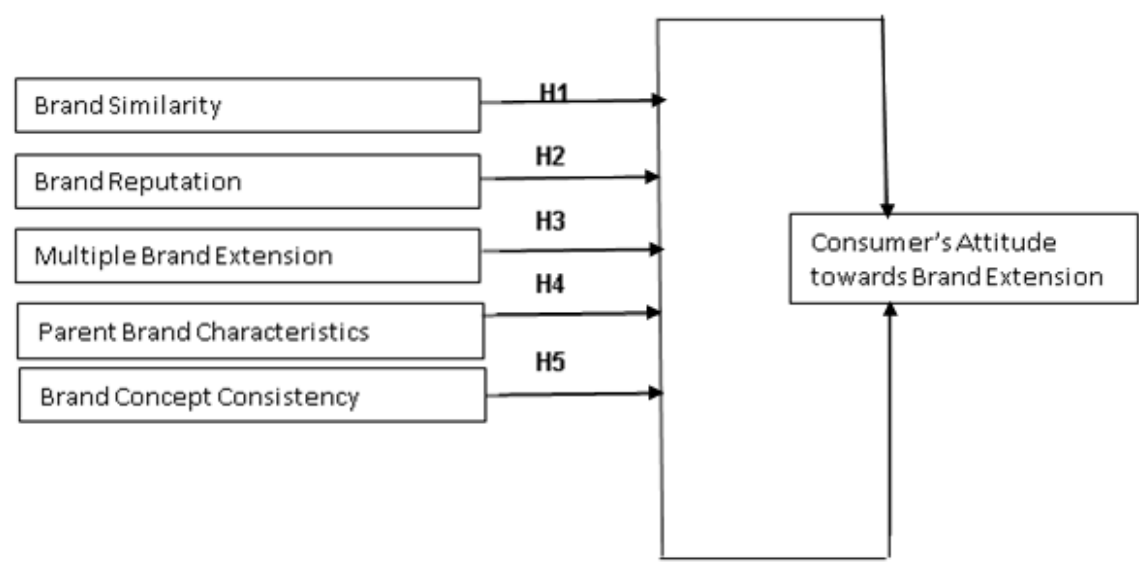

Figure1:

Factors Affecting Consumer's Attitude towards brand extension

\section{OBJECTIVE(S) OF THE STUDY}

The study objectives were to identify and empirically test the factors, which affect the consumer evaluation of brand extensions in reference to variables such as Brand Similarity, Brand Reputation, Multiple Brand Extension, Parent Brand Characteristics and Brand Concept consistency.

\section{LITERATURE REVIEW}

Branding has an ancient history. It could be traced back to the times when the ancient Egypt brick makers used to stamped symbols on the bricks for easily identification and distinction purposes (Farghuhar, 1990). Nilson (1998) on the other hand, also found that ancient farmers used to put symbols on their cattle with the help of hot iron, which meant burning. Similarly, the word brand has been derived from the Scandinavian word "branna" that means to burn. In Swedish language the word "brand" means fire. Thus when a producer put some marks or symbols on their product it will come thus in the category of branding (Nilson, 1998). It then, ultimately formed strong brands following the efforts by marketers and advertisers based on product qualities. One of the advantages of strong brand name is that its helps in penetrating in a new market with new or different product category.

Keller \& Aaker defines brand extensions as:

Brand extension is the strategy adopted by companies having strong and established brands names, as a means to enter in new product categories or classes (Keller \& Aaker, 1992).

It is a strategy commonly used by firms for using established and successful brand name for launching 
a new or modified product (Kotler \& Armstrong, 1990). Given the expense and risk of new product failures in today's dynamic and rapidly changing environment, brand extensions are mostly used as a strategy to enter into new markets.

The basic assertion on which brand extensions are based is that consumers hold positive attitude toward the parent brand that can be transferred to an extension without any negative consequences as long as there is a "fit" between the two (Aaker and Keller, 1990). This means that the brand-extension associations must be consistent with those of the parent brand in order for it to be a successful brand extension. In contrast, introducing brand extensions with inconsistent associations not only may fail and / or in some cases, can even dilute the parent brand equity (Loken and Roedder John, 1993).

Aaker and Keller (1990) explored the determinants of attitudes toward brand extensions and estimated a moderated regression model to test their hypotheses. Their findings revealed that consumer evaluations of brand extensions are based primarily on following factors: the extent of the fit between the original and the extended brands, the interface of the value of core brand with degree of fit between the original brand and the extended categories and the perceived difficulty of creating the extension product category.

Many studies on extension evaluation have focused on the issues surrounding "fit" between the core brands, its extension and moderating variables that may affect this fit. In order to avoid the high rates of failure of new products, the brand extension strategy has been used as one of the most profitable growth options for most of the companies now a day. The estimates fluctuate, but as a whole, eight out of every ten new products are launched through an extension of an established brand in some way (Ourusoff et al., 1992).

Even though, brand extensions assist in creating consumer positive attitude for a new product by making a link of newly launched product with established brand or company (Tauber, 1988). There is also a risk attached, of decreasing or harming the brand equity that has been built on core brand. Therefore, an improper brand extension may create destructive associations that may be very complex for a company to overcome even in a long time. Further, the decision also involves an important strategic expansion vision. If the judgment is wrong, considerable time, resources and numerous market opportunities may be lost (Ries and Trout, 1986; Aaker, 1990).

\subsection{Variables influencing brand evaluation}

a) Brand Similarity

Brand similarity refers to the degree of resemblance of consumer perception between extended and parent brand (Smith \& Park, 1992). If the level of similarity is higher between the parent and extended brand category then the brand extension would have great chances of inheriting the positive and negative characteristics of the core brand (Aaker \& Keller, 1990; Park et al., 1991 and Boush \& Loken, 1991). This assumption is primarily based on the premise that consumers attitude will be more positive towards those extensions where they find higher level of similarity between the extension and the parent brand (Boush et al., 1987).

A brand extension in a new product category is viewed as a new occurrence that can be more or less similar to the brand and its existing product line. Perceived similarity also called perceived fit is characterized by the "number of shared associations between the extension and the brand product category (Sandor Czellar, 2002). Researchers have identified two dimensions of the fit construct (Park et al., 1991; Bhat \& Reddy, 2001). The first is product category fit, which refers to the perceived similarity between the extension and the existing brand categories of the core brand. Other is known as brand-level fit, which refers to the match between the explicit image of the brand and the product category extension (Sandor Czellar, 2002). For a clear look, consider these two aspects of fit, think about Marlboro launching a ball-pen (Sandor Czellar, 2002). The perceived fit between Marlboro and the ballpen category will be comprised of a category-level fit (the shared product attributes between cigarettes and ballpens) \& a brand-level fit e.g. the match between Marlboro's brand image and the image consumer holds about the ball-pen category" (Bhat \& Reddy, 2001). 
A brand name can also serve as a category label, thus lead to a category-based evaluation of a new product extension (Park et al., 2002). Evaluating a brand extension somewhat involves a transfer process, wherein original brand associations are associated with the brand extension. Congruent with this theory, the evaluation of extensions is dependent upon their similarity to the core brand category, which has been conceptualized as a category-based processing phenomenon (Nan, 2006).

b)

\section{Brand Reputation}

The basic supposition in brand extension strategy is that the leverage providing capabilities of parent's brands to extensions differ from brand to brand. It is much higher for stronger brand and lower for weaker brand (Aaker \& Keller, 1992; Smith and Park, 1992). Brand reputation refers to "consumer's perceptions on the quality associated with a core brand" (Barone et al., 2000). When a consumer is first confronted to a brand extension, it is new and unfamiliar to him. Though, consumers may already be familiar with the core brand, they are expected to laid their evaluation regarding the extension upon their knowledge of the core brand.

Consumers may have many unrelated associations with a brand, one dimension of associations is brand attitude or affect, i.e. consumers' overall favorable or unfavorable evaluation of the core brand, while second dimension is related to associations consisting of beliefs about the brand's product and non-product attributes (Keller, 1993). It is therefore assumed that consumers transfer their associations with a core brand to an extension (Aaker and Keller, 1990). The consumers are likely to evaluate those brands more positively that have higher perceived quality as compared to low perceived quality brands (Bottomley \& Doyle, 1996). Categorization theory suggests that when an individual faces a new occurrence of a category, the affect associated with that category is transferred to the newly categorized member (Fiske and Pavelchak, 1986). This is known a "category-based mode" of affective response since the foundation of affect formation is simply membership in a category and not the attributes of the new object (Fiske and Pavelchak, 1986).

A brand extension, by virtue of its name, is a member of the mental category of the core brand in consumers' minds. Consumers have affect associated with the brand, which stirs up when they encounter an extension" (Boush et al., 1987; MacInnis and Nakamoto, 1991). Reputation in the above studies have been conceptualized as a combination of (a) product quality (b) firm's marketing activities and (c) acceptance in the market place (Fombrun \& Van Riel, 1997).

Consumer when evaluating highly perceived reputation brand would feel that it is comparatively less risky; therefore, their evaluations would be more positive towards these brands as compared to brands having lower brand reputation (Wernerfelt, 1988). Positive emotional appeals also provide a strong brand cue and stimulate categorybased processing. In addition, the absence of extension formation will not only cause individuals to rely on available diagnostic cues like brand name, perceived parent brand quality, but perceived fit also to make inferences on the extension (Klink and Smith, 2001). This belief is consistent with the findings of earlier studies on extension evaluation (Aaker and Keller, 1990). As more information is available on new brand extension, new characteristics of the extension become salient which position the extension further from the parent brand (N. Jahangir et al., 2009).

The brand association is dynamic for those firms that aggressively follow expansion strategy through multiple brand extension given the fact that consumer perception of brand image and its association vary with the introduction of brand extension (Tariq Jalees and Tahir Ali, 2008). Therefore, this process has an impact on the perception of fit between a brand and its future extension. While introducing new brand extension, the consumers bring to mind the previous perception of the brands and alter it accordingly, which affect the fit between a brand and its future extension (Lynch \& Thomas, 1982). Keller (1992) has proposed "the relationship between parent brand and its extension would be moderated on previous brand extension history and the quality levels of the parent brand." If the firm has an account of brand extension, then the consumer, while evaluating the brand extension would see (1) whether previous extensions were successful or not (2) If there is any similarity in the parent brand and its proposed extension (Keller, 1992). If the brand extension were "dissimilar" or lacked fit then it will negatively affect the consumer quality perception and consumer attitude will also be adversely affected. 
The new brand extension would also be affected if there is no similarity between the quality of the parent brand and intermediate extension. If the quality of the intermediate brand is lower than the parent brand, the consumer's evaluation would be considerably low. Intermediate brand will improve perception of core brand if the quality of intermediate brand is of moderate level. If there is uniformity between intermediate and parent brand then there will be no change of perception on proposed brand extension (Kapoor, 2005).

Along with transfer of affect to a new category member, many researchers also proposed the existence of a more complex processing mechanism in the evaluation of new extension. When they view a new instance of a known category, individuals probably infer the non- perceptible attributes of the new member based on their knowledge of the category (Smith and Medin, 1981). Other than core brand associations (i.e. attributes and affect), perceptions of fit between the parent brand and its extension are another important factors in extension evaluation process. Many studies (e.g. Aaker and Keller, 1990; Bousch \& Loken, 1991) have bickered that consumers consider brand extension as a paradigm of the parent brand category.

When faced with an extension for the first time, the tangible and intangible attributes of the parent brand may be induced in consumer minds, and these may then be inferred in the extension (Boush and Loken, 1991). According to Broniarczyk and Alba (1994), "the impact of parent brand affect extension evaluation, was moderated by the relevance of specific parent brand associations in the extension's product category. Further, extensions of less liked brands were better evaluated, when they were in product categories where their parent brand associations were seen as more relevant than extensions of better liked brands whose associations were not seen as relevant in the category, offering even stronger evidence of the importance of specific parent brand associations."

\section{d)}

\section{Parent Brand Characteristics}

The terms such as product attributes, benefits and customers characteristics are generally used for conceptualization of brand association (Keller, 1993). Brand names such as Sony have broader association and can be used for diversified range of products. The brand such as close-up has narrow association and is used for one or few products (Bousch \& Loken, 1991). As per Dacin \& Smith (1997), "Product portfolio characteristics of parent brand generally have moderating effect on product category fit and the evaluation of parent brand." Their major findings include: The consumer's confidence on brand extension evaluation would be favorable for brands those are associated with several products, given that there is no significant similarity between the qualities of products. Their research results also specify that arbitrarily brand extensions into unrelated product, provided that the feature and value of the parent brand is high, are still not advisable.

Therefore, the first extension should be into moderated categories and then to unrelated category. This gradually stepwise extension from one category to moderated unrelated category would assist the consumers in maintaining the perception of relatedness. A brand name may have association with several products, but the level of association of all the products related to brand may differ. Brand extension having strong association with the core brand, could be easily evaluated by the consumers, as oppose to products that have weaker association with the core brand (Kapoor, 2005). In other words, the more similar the extension is to a parent brand, the more likely are consumers to infer the parent brand's characteristics in the brand extension. Empirical support from many studies verifies that higher the "fit", the more positive extension evaluation would be (Aaker and Keller, 1990; Boush and Loken, 1991).

\section{e) Brand Concept Consistency}

The market is vibrant. In response to dynamic markets, firms modify their offerings, enter different market segments, and sometime reposition their offerings. In view of such complexities, the measure of fit while introducing brand extension may be relevant in one situation and not in another situation (Kapoor, 2005).

Park et al., (1991) were of the opinion that consumer evaluation would only be favorable for those brand extensions that have consistency in the brand concept. Brand concept is Brand unique abstract, and meaning e.g. high class that usually is created from a certain type of brand features i.e. high price, expensive looking design, etc., and firms efforts to create meanings for these arrangements e.g. the persistent pursuit for perfection by Lexus (Park et al., 1991, p.186). 
Object similarity may be necessary, but may not fully explain the brand category fit for an extension. Two objects may have several common physical attributes, but the brand concepts of both the objects may be completely different to each other e.g. Sieko and Rolex watches share numerous product level features but as far as brand concepts of the two watches are concerned, Seiko has reputation as functional brand and Rolex as prestige brand (Park et al., 1991). Thus, the perceived fit is combination of: (1) product feature similarity and (2) brand concept consistency (Kapoor, 2005).

\section{HYPOTHESES}

To be able to determine consumer attitude towards brand extension, following hypotheses are developed:

H1: Brands extended to similar category would have a positive consumer evaluation.

H2: The consumer evaluation of brand extension would be positive for those brand extensions whose parent's brand has stronger reputation.

H3: Consumer evaluation would be positive for those companies that have a reputation of introducing multiple brand extensions.

H4: Consumer would evaluate those brands positively that have strong association as compared to those that have weaker association.

H5: The consumer's brand evaluation would be positive for those brands that have more concept consistency.

\section{RESEARCH METHODOLOGY}

\subsection{Selection of Brands Extensions}

The original brands were selected as per criteria of being relevant to subjects, generally perceived as high quality in their product class, able to elicit comparatively specific associations, and not very broadly extended previously. Two brands were chosen as stimuli i.e. Olpers cream and Tapaltea bag. But efforts have been put to choose brands in such a manner that one of them should be a national and other an international brand to get better view of consumers' attitude toward multinational and national company's brands (Olpers is famous national brand of Pakistan owned by Engro Corporation whereas, Lipton belongs to Unilever a renowned MNC). Thus, the following two brand extensions were finalized for further study:

\begin{tabular}{|ll|c|}
\hline \multicolumn{1}{|c|}{ Parent Brand } & Brand Extension \\
\hline 1) & Lipton tea & Lipton Tea Bag \\
\hline 2$)$ & Olpers Milk & Olpers Cream \\
\hline
\end{tabular}

\subsection{Dependent Variable}

The dependent variable for the study was "brand extension's overall evaluation". As Keller and Aaker (1992) have used the similar statement for measuring overall evaluation: I am positive to the extension of XYZ. For measuring the consumer's evaluation toward brand extensions, we also used the same approach for measuring consumer evaluation of brand extension.

\subsection{Independent Variable(s)}

i) Brand Similarity

Brand similarity between the core and its extension was measured by using the concepts of Aaker \& Keller (1990) and Smith \& Park (1992) by asking the respondents to rate the brand similarity between the original and extended brands of the two brand extensions used in this study as stimuli. 


\section{ii) Parent Brand Reputation}

Aaker and Keller (1990) and Loken \& John (1993) have used alike method for measuring the reputation of core brand. The statements derived from their definitions were: (1) Altogether; i am very positive with the brand e.g. GHT (2) Altogether; i am very satisfied with the brand GHT (3) Altogether; i associate positive things with the brand GHT. The current study also used these statements with similar approach in the questionnaire.

iii)

\section{Multiple Brand Extensions}

Aaker (1992) brought into being a relationship between the brand extension history and the consumer evaluation of the brand. Respondents of current study were asked to rate the reputation of the firms for introducing multiple brands.

\section{iv) Parent Brand Characteristics}

Smith (1994) has defined parent brand's characteristics in reference to broad and narrow association. Brands like 'Sony' have broad association as these brand names are used with several products. However, the brands like 'Colgate' e.g. have very narrow association as this brand name can only be used for limited number of products. Based on this construct, the respondents were requested to rate the selected brands in terms of broad and narrow association.

v)

\section{Parent Brand Consistency}

We adopted variable parent consistency defined by Park et al., (1991) in terms of product's price and design. In current study, the respondents were asked to rate the selected brands in terms of price and design perception.

\subsection{Data Collection}

The research is primary data based. The respondents of the study are consumers in Bahawalpur District (Pakistan). Traditionally, many studies (e.g. A\&K, Keller, \& Harish Kapoor, etc.) were conducted to evaluate the consumer attitude toward brand extension choose students as their respondents due to convenience or other reasons, but we targeted actual consumers instead of students to get a better insight.

\subsection{Sample Size determination}

Stratified proportionate sampling technique (in proportion to the population of each Union Council) was used for drawing the samples. The sample size for study was 430 consumers of Bahawalpur district. Out of 430 questionnaires, 400 questionnaires were finally received, and subsequently used for further analysis.

Table 1

Sample collection Detail for Bahawalpur District

\begin{tabular}{|c|c|c|c|c|}
\hline \multirow{3}{*}{ Sr. No. } & District & Tehsil & No. of Union Councils & Total No. of Samples \\
\hline \multirow{3}{*}{1.} & Bahawalpur & Bahawalpur & 18 & 91 \\
\cline { 3 - 5 } & & Hasilpur & 13 & 66 \\
\cline { 3 - 5 } & & Ahmedpur East & 30 & 152 \\
\cline { 3 - 5 } & & Yazman & 17 & 86 \\
\cline { 3 - 5 } & & Khairpur & 07 & 35 \\
\hline
\end{tabular}

\subsection{Research Instrument}

Data was collected by using structured questionnaire adopted form the study of Tariq Jaless and Tahir Ali 
(2008). However, certain modifications were made to the questionnaire regarding products. Authors(s) also conducted a pilot survey before actual data collection. Respondents eagerly accepted the wordings and positive responses were received. After pilot survey, actual data collection started. The instrument contained 14 questions related to brand extension's similarity, parent brand's consistency, reputation, characteristics and reputation of introducing multiple brands. Respondents of the study were asked to rate their opinion on a five point likert scale 1 being strongly disagree and 5 being strongly agree.

\subsection{Data Analysis}

Data was entered, edited and analyzed by using Softwares, SPSS version 17 and Microsoft Excel 2007 by applying following techniques: Cronbach's alpha, Multicollinearity, Correlation and Regression.

\section{Cronbach's Alpha}

To check the internal reliability of the instrument, Cronbach's alpha was run. The value of Cronbach's Alpha comes to 0.931 . Which is above the standard value proposed by (Nummally, 1978) of 0.70 this shows that our instrument is reliable and we can confidently apply different statistical tests and interpret the results with confidence.

\section{Correlation Analysis}

Pearson correlation was run to check the relationship of variables with each other and whether any observed variable has perfect covariance with any other variables, which are observed in the study. We applied correlation to both brand extensions. Summarized results of correlation are shown in table-2 below. All relationships were found significant at $\mathrm{p}$ value of 0.01 . These relationships shows a positive and moderate to strong relationships. We discussed correlation results of each extension separately. In case of Olpers Cream, results suggest that all the variables are positively correlated to overall evolution of brand Olpers Milk.

The most correlated variable was design consistency Olpers Cream, with correlation value of 0.766 . It was followed by reputation of introducing multiple brands Olpers milk having correlation value of 0.734 .

Table 2

Correlation

\begin{tabular}{|c|c|c|c|c|c|c|c|c|c|c|c|c|c|c|c|}
\hline & Variables & OEOC & $\mathrm{BOC}$ & $\mathrm{BROC}$ & RIMBO & $\mathrm{AO}_{0}$ & $\mathrm{PCOC}$ & $D C O C$ & OELTB & BLTB & BRLTB & RIMBLT & AL & PCLT & DCLT \\
\hline OEOC & Overall Evaluation of Brand Olpers Cream & 1 & & & & & & & & & & & & & \\
\hline $\mathrm{BOC}$ & BrandSimilarity 0lpers Cream & 0.698 & 1 & & & & & & & & & & & & \\
\hline BROC & Brand Reputation Olpers Cream & 0.545 & 0.583 & 1 & & & & & & & & & & & \\
\hline RIMBO & Reputation of Introdudig Multiple Brand Olpers Millk & 0.734 & 0.644 & 0.605 & 1 & & & & & & & & & & \\
\hline A0 & Ass aciation 0lpers & 0.687 & 0.71 & 0.63 & 0.67 & 1 & & & & & & & & & \\
\hline $\mathrm{PCOC}$ & Price Consistenof Olpers Cream & 0.699 & 0.67 & 0.469 & 0.657 & 0.706 & 1 & & & & & & & & \\
\hline DCOC & Des ign Cor istency Olpers Cream & 0.766 & 0.633 & 0.464 & 0.604 & 0.692 & 0.69 & 1 & & & & & & & \\
\hline OELTB & Overall Evaluation of Brand Liptontea Bag & 0.768 & 0.64 & 0.449 & 0.667 & 0.595 & 0.673 & 0.644 & 1 & & & & & & \\
\hline ELLTB & BrandSimilarity LiptonteaBF & 0.709 & 0.66 & 0.541 & 0.677 & 0.562 & 0.608 & 0.55 & 0.791 & 1 & & & & & \\
\hline BRLTB & Brand Reput ation LiptonteaBF & 0.513 & 0.516 & 0.453 & 0.492 & 0.443 & 0.453 & 0.395 & 0.563 & 0.545 & 1 & & & & \\
\hline RIMBLT & Reputation of Introdudig Multiple Brand LiptonTea & 0.682 & 0.643 & 0.55 & 0.762 & 0.604 & 0.663 & 0.601 & 0.697 & 0.789 & 0.533 & 1 & & & \\
\hline AL & Ass aciation Liptan & 0.709 & 0.664 & 0.469 & 0.613 & 0.697 & 0.637 & 0.608 & 0.718 & 0.706 & 0.542 & 0.742 & 1 & & \\
\hline PCLT & Price Consisteno/ Liptontea B⿸尹口 & 0.624 & 0.533 & 0.43 & 0.601 & 0.58 & $0 . \overline{2} 2$ & 0.45 & 0.67 & 0.658 & 0.538 & 0.631 & 0.7 & 1 & \\
\hline DCLT & Des ign Corristency Liptontea B⿸尸 & 0.652 & 0.631 & 0.475 & 0.628 & 0.534 & 0.627 & 0.623 & 0.73 & 0.659 & 0.581 & 0.708 & 0.7 & 0.64 & 1 \\
\hline
\end{tabular}


Price consistency olpers cream and brand similarity olpers cream comes third and fourth with correlation values of 0.699 and 0.698 respectively. Association olpers and brand reputation olpers cream are sixth and seventh with least correlated values of 0.687 and 0.545 respectively.

While discussing second brand extension Liptontea bag, table-2 suggests that the most correlated variable was overall evaluation of brand liptontea bag with correlation value of 0.768 . Brand similarity Liptontea bag and Association Lipton both have correlation value of 0.709 . Then, reputation of introducing multiple brands lipton tea comes having correlation value of 0.682 followed by design consistency Liptontea bag with correlation value of 0.652. Price consistency liptontea bag and brand reputation liptontea bag are thereafter having correlation values of 0.624 and 0.513 respectively.

\section{Multicollinearity}

In order to see whether the variables are not very much correlated, we checked the multicollinearity of independent variables.

Table 3: Multicollinearity of Independent Variables

\begin{tabular}{lll}
\hline Collinearity Statistics & Tolerance & VIF \\
\hline Brand Similarity Liptontea Bag & 0.316 & 3.169 \\
Brand Reputation Liptontea Bag & 0.588 & 1.701 \\
Reputation of Introducing Mul tiple Brands Liptontea & 0.281 & 3.558 \\
Association Lipton & 0.365 & 2.737 \\
Price Consistency Liptontea & 0.449 & 2.227 \\
Design Consistency Liptontea & 0.397 & 2.520 \\
Brand Similarity Olpers Cream & 0.390 & 2.563 \\
Brand Reputation Olpers Cream & 0.520 & 1.925 \\
Reputation of Introducing Multiple Brands Olpers Milk & 0.417 & 2.400 \\
Association Olpers & 0.315 & 3.174 \\
Price Consistency Olpers Milk & 0.369 & 2.709 \\
Design Consistency Olpers Milk & 0.423 & 2.367
\end{tabular}

The results of the multicollinearity can be seen in the table- 3 above. Collinearity is assessed by using the tolerance (TOL) and variation-inflation factor (VIF). Collinearity is found if TOL is less than 0.2 and the VIF more than 5, respectively. The results in table show that maximum VIF is 3.558, which is lower than 5, a number that is used as a rule of thumb as an indicator of multicollinearity problems (Belsely, 1991). In addition, minimum TOL is 0.281 , which is more than 0.2 . Thus, these results support the lack of presence of multicollinearity in the research model. The results of the regression analysis can, therefore, be interpreted with a greater degree of confidence.

\section{REGRESSION ANALYSIS}

To analyze the hypothesis proposed on one to one basis and since both dependent and independent variable(s) are quantitative, classical regression technique can be applied with confidence.

\subsection{Hypothesis One}

The hypothesis postulates that brand extension to similar category would have positive consumer evaluation as compared to those brands extended to non-similar category. Hypothesis developed is:

H1: Brands extended to similar category would have a positive consumer evaluation. 
Two brand extensions were used as stimuli.

Summarized Regression Results are:

Table 4

\begin{tabular}{|c|c|c|c|c|c|c|}
\hline \multicolumn{7}{|c|}{ Summarized Regressions on Overall Evaluation and Brand Similarity } \\
\hline Parent Brand & Brand Extension & R-Square & t-value & Coefficient & F-Value & P-value \\
\hline Lipton Tea & Liptontea Bag & .626 & 25.827 & $\begin{array}{c}0.791 \\
(.727)^{*}\end{array}$ & 667.017 & $p=0.000$ \\
\hline Olpers Milk & Olpers Cream & .487 & 19.438 & $\begin{array}{c}0.698 \\
(.666)^{*}\end{array}$ & 377.840 & $p=0.000$ \\
\hline
\end{tabular}

* Unstandardized Beta Coefficients in parenthesis

\section{Brand Extension No. 1 (Liptontea Bag)}

The value of $\mathrm{R}^{2}$ is 0.626 , which shows that $62.6 \%$ of the variance in overall evaluation of brand Liptontea bag is explained by predictor variable. The value of $\mathrm{F}$ test is 667.017 at $\mathrm{p}<0.000$ shows the model's goodness of fit. The $\mathrm{t}$ value is more than +2 , which indicates that there is a positive relationship between variables. Hence, our $\mathrm{H} 1$ is accepted and we conclude that brands extended to similar category would have a positive consumer evaluation.

\section{Brand Extension No. 2 (Olpers Cream)}

In this case, the value of $\mathrm{R}^{2}$ is 0.487 , showing that $48.70 \%$ of the variance in overall evaluation of brand Olpers cream is explained by predictor variable. The value of $\mathrm{F}$ test is 377.840 with $\mathrm{p}<0.000$ shows the model's goodness of fit. The value of $t$ is greater than $+2(p<0.000)$ indicates that there is a positive relationship between variables. Hence, $\mathrm{H} 1$ is accepted. From this relation it can be concluded that the respondents found high levels of similarities between brand extensions of Olpers cream and Liptontea bag.

\subsection{Hypothesis Two}

This hypothesis postulates that the evaluation of brand extension would be positive for those brands whose parent's brands have stronger reputation. Hypothesis is:

H2: The consumer evaluation of brand extensions would be positive for those brand extensions whose parent's brand has stronger reputation.

Summarized Regression Results are:

Table 5

\begin{tabular}{|c|c|c|c|c|c|c|}
\hline \multicolumn{7}{|c|}{ Summarized Regressions on Overall Evaluation and Parent Brand Reputation } \\
\hline Parent Brand & Brand Extension & R-Square & t-value & Coefficient & F-Value & P-value \\
\hline Lipton Tea & Liptontea Bag & .317 & 13.589 & $\begin{array}{c}0.563 \\
(.555)^{*}\end{array}$ & 184.660 & $p=0.000$ \\
\hline Olpers Milk & Olpers Cream & .297 & 12.968 & $\begin{array}{c}0.545 \\
(.509)^{*}\end{array}$ & 168.167 & $p=0.000$ \\
\hline
\end{tabular}

* Unstandardized Beta Coefficients in parenthesis

\section{Brand Extension No. $1 \quad$ (Liptontea Bag)}

The value of $\mathrm{R}^{2}$ shows that $31.70 \%$ of the variance in overall evaluation of brand Liptontea bag is explained by predictor variable. The value of $F$ test is 184.660 with $p<0.000$. This shows the model's goodness of fit. The value of $t$-test for preparedness is well above +2 with significant $p$ value of $p<0.000$ indicates that there is a 
positive relationship between variables and hence $\mathrm{H} 1$ is accepted, the significance of this relationship helps in concluding that the consumer evaluation of brand extension would be positive for those brand extensions whose parent's brand has stronger reputation.

\section{Brand Extension No.2 (Olpers Cream)}

Here, in this case, $\mathrm{R}^{2}$ shows that $29.70 \%$ of the variance in overall evaluation of brand olpers cream is explained by predictor variable. The value of F-test is 168.167 with $t>+2$ at $\mathrm{p}<0.000$. Hence, we accept $\mathrm{H} 2$. The results indicate that medium relationships exist on brand reputation.

\subsection{Hypothesis Three}

This hypothesis assumes that the consumer evaluation of those brand extensions would be positive that have history of introducing multiple brands. A hypothesis developed is as:

H3: Consumer evaluation would be positive for those companies that have a reputation of introducing multiple brand extensions.

Summarized Regression Results are:

Table 6

\begin{tabular}{|c|c|c|c|c|c|c|}
\hline \multicolumn{7}{|c|}{ Summarized Regressions on Overall Evaluation and Parent's Reputation of Introducing Multiple Brands } \\
\hline Parent Brand & Brand Extension & R-Square & t-value & Coefficient & F-Value & P-value \\
\hline Lipton Tea & Liptontea Bag & .486 & 19.390 & $\begin{array}{c}.697 \\
(.681)^{*}\end{array}$ & 375.957 & $p=0.000$ \\
\hline Olpers Milk & Olpers Cream & .538 & 21.550 & $\begin{array}{c}.734 \\
(.713)^{*}\end{array}$ & 464.403 & $p=0.000$ \\
\hline
\end{tabular}

* Unstandardized Beta Coefficients in parenthesis

\section{Brand Extension No. 1 (Liptontea Bag)}

Here $\mathrm{R}^{2}$ shows that $48.60 \%$ of the variance in overall evaluation of brand Liptontea bag is explained by predictor variable. The value of $F$ test is 375.957 while $t$-value is greater than $+2(p<0.000)$. This shows the model's goodness of fit and the existence of relationship between variables in explaining the variations. Therefore, our $\mathrm{H} 3$ is accepted and it is conclude that consumer evaluation would be positive for those companies that have a reputation of introducing multiple brand extensions.

\section{Brand Extension No. 2 (Olpers Cream)}

In this brand extension, the value of $\mathrm{R}^{2}$ shows that $53.8 \%$ of the variance in dependent variable is explained by predictor variable. The value of $\mathrm{F}$ test is 464.403 while value of $\mathrm{t}$-test is greater than +2 at $\mathrm{p}<0.000$ thus making it a useful predictor. Hence, $\mathrm{H} 3$ is accepted.

\subsection{Hypothesis Four}

With the help of current hypothesis, authors tried to evaluate whether consumer evaluation of those brand extensions would be positive that have strong association and vice versa. Association means flexibility in the brand name for extending into various product categories. A hypothesis formed is:

H4: Consumer would evaluate those brands positively that have strong association as compared to those that have weaker association. 


\section{Summarized Regression Results are:}

Table 7

\begin{tabular}{lccccc}
\hline \multicolumn{5}{c}{ Summarized Regressions on Overall Evaluation and Association } \\
\hline Parent Brand & R-Square & t-value & Coefficient & F-Value & P-value \\
Lipton Tea & .515 & 20.573 & 0.718 & 423.241 & $p=0.000$ \\
& & & $(.710)^{*}$ & & \\
Olpers Milk & .472 & 18.877 & 0.687 & 356.351 & $p=0.000$ \\
& & & $(.664)^{*}$ & & \\
\hline
\end{tabular}

* Unstandardized Beta Coefficients in parenthesis

\section{Brand No. 1 (Lipton Tea)}

The value of $\mathrm{R}^{2}$ explains that $51.50 \%$ of the variance is explained by predictor variable. The value of $\mathrm{F}$ test is 423.241 while value of $\mathrm{t}$-test is greater than +2 at $\mathrm{p}<0.000$. Therefore, we accept $\mathrm{H} 4$ and conclude that consumer would evaluate those brands positively that have strong association as compared to those that have weaker association. This may be because as stronger association has been developed in the consumers' mind, which helps them to quickly associate the new extension's quality to parent brands and ultimately helping in evaluation process.

\section{Brand No. 2 (Olpers Milk)}

Here $\mathrm{R}^{2}$ illustrates that $47.2 \%$ of the variance in dependent variable is explained by predictor variable Association Olpers. The value of $F$ test is 356.351 with $t$ value of 18.877 at $p<0.000$. The relationships between the Multiple Branding and overall evaluation were found to moderate for both Lipton tea and Olpers milk with R-square being 0.515 and 0.472 respectively. The beta values were 0.718 and 0.687 for Lipton tea and Olpers milk respectively. Hence, we accept $\mathrm{H} 4$ in this case also.

\subsection{Hypothesis Five}

This hypothesis put forwards that the consumer evaluation of those brands extension would be positive whose parent brands have more concept consistency. Concept consistency relates to Price and Design. Hypothesis is given as:

H5. The consumer's brand evaluation would be positive for those brands that have more concept consistency.

Summarized Regression Results are:

Table 8

\begin{tabular}{lccccc}
\hline \multicolumn{5}{c}{ Summarized Regressions on Overall Evaluation and Price Consistency } \\
\hline Parent Brand & R-Square & t-value & Coefficient & F-Value & P-value \\
Lipton Tea & .449 & 17.995 & .670 & 323.825 & $p=0.000$ \\
& & & $(.658)^{*}$ & & \\
Olpers Milk & .489 & 19.504 & .699 & 380.409 & $p=0.000$ \\
& & & $(.675)^{*}$ & & \\
\hline
\end{tabular}

* Unstandardized Beta Coefficients in parenthesis

\section{Consistency Related to Price}

\section{Brand Extension No. 1 (Liptontea Bag)}

Here the value of $\mathrm{R}^{2}$ explains that $44.90 \%$ of the variance in dependent variable is explained by predictor 
variable. The value of $\mathrm{F}$ test is 323.825 with $\mathrm{t}$-value being more than +2 and $\mathrm{p}<0.000$. Therefore, we accept $\mathrm{H} 5$ at and conclude that the consumer's brand evaluation would be positive for those brands that have more concept consistency in terms of price.

\section{Brand Extension No. 2 (Olpers Cream)}

The value of $\mathrm{R}^{2}$ clarifies that $48.90 \%$ of the variance in dependent variable is explained by predictor variable. The value of F-test is 380.409 with value of $t$ being 19.504 at $p<0.000$. This shows the goodness of fit and makes it a useful predictor. Hence, we accept $\mathrm{H} 5$ for brand extension olpers cream with respect to price consistency. The relationship between the price consistency and overall evaluation were found to moderate for both Liptontea and Olpers with $\mathrm{R}^{2}$ being 0.449 and 0.489 respectively. The beta values were 0.670 and 0.699 for Liptontea and Olpers respectively.

\section{$\underline{\text { Design Consistency }}$}

Summarized Regression Results are:

Table 9

\begin{tabular}{lccccc}
\hline & \multicolumn{5}{c}{ Summarized Regressions on Overall Evaluation and Design Consistency } \\
\hline Parent Brand & R-Square & t-value & Coefficient & F-Value & P-value \\
Lipton Tea & .533 & 21.315 & .730 & 454.308 & $p=0.000$ \\
& & & & $(.751)^{*}$ & \\
Olpers Milk & .586 & 23.757 & .766 & 564.379 & $p=0.000$ \\
& & & & $(.738)^{*}$ & \\
\hline
\end{tabular}

* Unstandardized Beta Coefficients in parenthesis

\section{Brand Extension No. 1 (Liptontea Bag)}

The value of $\mathrm{R}^{2}$ illustrates that $53.3 \%$ of the variance in dependent variable is explained by variable design consistency Lipton tea. The value of F test is 454.308 and value of t-test is 21.315 at $p<0.000$. Hence, H5 is accepted with respect to design consistency and we conclude that the consumer's brand evaluation would be positive for those brands that have more concept consistency in terms of design.

\section{Brand Extension No. 2 (Olpers Cream)}

In this extension, the value of $\mathrm{R}^{2}$ shows that $58.60 \%$ of the variance in dependent variable is explained by predictor variable. The value of $\mathrm{F}$ test is 564.379 and $\mathrm{t}$-test value is $23.757(\mathrm{p}<0.000)$. The relationship between price consistency and consumer evaluation was strong for brand Lipton with coefficient of determination being 0.489 and relatively weak for Olpers with coefficient of determination being 0.449 , while their betas were 0.699 and 0.670 respectively. In design consistency, $\mathrm{R}^{2}$ for Olpers was significantly stronger than Lipton being 0.586 and 0.533 with beta 0.766 and 0.730 respectively. This indicates that in the relationship of consistency and overall evolution of Brand Olpers, the contribution of design is comparatively stronger, than the contribution of price. For the brand, Lipton the coefficient of design is stronger than the coefficient of price. So, H5 is accepted.

\section{DISCUSSION}

A brand is one of the most important assets for any firms and due to this reason, marketing managers and / or brand managers ought to be alert for inadequate strategies that erode brand assets. Probably, one of the perilous strategies involves the launching of inappropriate and unsuitable brand extensions that corrode extended brand benefits and associations (Martínez and de Chernatony, 2004; Diamantopoulos et al., 2005). According to the literature, core parent brand experience positively influences probability of extension trial (Swaminathan et al., 2001; Swaminathan, 2003), and our results reveal a direct effect of brand experience or brand familiarity on consumer attitude to brand extensions. 
Our findings validate previous results in the literature concerning the positive effects of perceived fit, either category or image fit, on consumer attitude (e.g. Völckner et al., 2008, Aaker and Keller, 1990, Broniarczyk, 1994, Keller, K. L., 1993 and Dacin, P.A., Smith, D.C. 1997 and study conducted by Tariq Jalees and Tahir Ali, 2008).

While, it is suggested that perceived fit (category and image) has direct effect on the image of extended brand, though an indirect effect occurs through attitude to the extension. A high fit perception usually leads to categorization process in which the brand extension is associated to the brand category and leverages the existing beliefs and attitudes (Monga and Houston, 2002). More specifically, we can say that a high fit will involve the leveraging of the attitude to the brand extension. The results obtained are thus in line with those works that indicate that consumer attitude toward brand extensions mainly depends on perceived fit (Aaker and Keller, 1990; Van Riel et al., 2001; Völckner and Sattler, 2006). So, attitude towards brand extension is particularly determined by perceived category fit and initial brand image, which, in turn depends on brand familiarity.

\section{RECOMMENDATIONS}

Following recommendations are proposed our current study scenario:

- The firms whose brands have strong reputation could afford the luxury of venturing into distance brand extension based on their brand reputation and equity. However, the firms, whose brands have weaker reputation they should either focus on enhancing their brand reputation or extent their brand in the same category.

- $\quad$ The firms that are extending their brands to similar category or close extension should target the consumers that have been high level of innovativeness. On the other hand, companies that are extending their brands into different category or distance extension must target those customers that have high level of perceived risk.

- $\quad$ Similarly, in case of close extensions such as Lipton tea and tea bag, the firm must concentrate on the design rather than price consistency. In addition, companies should also concentrate on packaging in order to remain competitive in this age of hyper competition.

- In case of distance extension, the firms must not extend their brands to a category that consumer would not consider a substitute or complement. Therefore, in this case, despite knowing, firms dare to extend into these categories assuming that while evaluating their extension, the customers will take cues from the reputation of the company.

- $\quad$ Firms should be careful in application of brand extension strategy / multi-brand as it could have negative effects on the core brand and would adversely affect the reputation of the core brand.

\section{CONCLUSION}

This study helps in understanding how core brand's reputation, quality, beliefs and equity affect the evaluations of extension. It also indicates that highly rated brand extensions considered to be a good fit with the parent brand, are not evaluated as favorably in the presence of competing brands or when the extensions brand's quality or price is not consistent with the parent brand's quality or price level. This means that the core brand extension must create a "fit" not only with the core brand, but it must bring in with the enough knowledge of the upshot of the competing brands in that category. The focus of the study was to determine the consumer's attitude towards brand extension based on five factors i.e. brand similarity, brand reputation, multiple brand extensions, parent brand characteristics and brand concept and consistency. The summarized results are presented below:

a) The respondents found high levels of similarities between brand extensions of Liptontea having extension of Lipton tea bag and Olpers Milk with its extension Olpers Cream.

b) The results indicate that medium relationships exist between variables brand reputation and consumer evaluation for the brand extensions lipton tea bag and olpers cream.

c) The relationships between variables perception of multiple branding and overall evaluation was found to be moderate.

d) The relationships between multiple branding and overall evaluation were found to moderate for both lipton and olpers. 
e) The relationship between variables price consistency and consumer evaluation was found to be strong for brand olpers and weak for lipton. In design consistency, olpers is significantly stronger than lipton. This indicates that in the relationship of consistency and overall evolution of Brand Olpers, the contribution of design is comparatively stronger, than the contribution of price.

\section{RESEARCH LIMITATIONS}

The study has following limitations:

First, the subject study's finding could not be generalized broadly based on two products group. However, increasing the products groups would be a positive step for generalizability. Secondly, sample size was limited. With large sample size, interesting results can be achieved. Thirdly, our data is based on the responses of respondents living in one District (Bahawalpur) only. Therefore, this fact cannot allow generalizations across different cultures. Study by Bottomley and Holden (2001) also emphasis on this issue. They described that generalizability of study conducted by Aaker and Keller (1990) and emphasized that uniform strong effects of fit and parent brand quality across cultures. In simpler words, "cultural differences did not change the scenario that fit and core brand quality are important factors of brand extension success" (Völckner and Sattler, 2005). Fourthly, our findings are limited to FMCG sector only but extending to other fields like services sector may produce informative insights.

\section{AUTHOR INFORMATION}

Zain Ul Abideen did MSMS (Marketing) from Shaheed Zulfikar Ali Bhutto Institute of Science \& Technology (SZABIST), Islamabad Campus, Pakistan while B.Sc (Mathematics), MBA (Marketing) and M.Sc in Economics from the Islamia University of Bahawalpur, Pakistan. Zain served as Assistant Manager in NADRA (National Database \& Registration Authority) Govt. of Pakistan, Senior Marketing Manager in KARL Chemical Works, Lahore, Pakistan and Nestle Pakistan, while currently associated with The Islamia University of Bahawalpur, Pakistan.

Abdul Latif is Chairman, Department of Management Sciences, The Islamia University of Bahawalpur, Pakistan. He holds PhD from the Australian National University (ANU), Australia. He has rich experience of teaching and research.

\section{REFERENCES}

1. $\quad$ Aaker, D. A. 1992. Strategic Marketing Management (3rd Ed.). Canada: John Wiley \& Sons, Inc.

2. Aaker, D. A. and Keller K.L. 1990. Consumer Evaluation Brand Extension. Journal of Marketing, 54(January), 27-41.

3. Barone, J. M. Miniard J, W.P. and Romeo, B.J., 2000. The Influence of Positive Mood on Brand Extension Evaluations. Journal of Consumer Research, 26 (March), pp. 386-400.

4. Belsely, D.A., 1991. Conditioning Diagnostics: Collinearity and Weak Data in Regressions. Wiley, New York, NY

5. Broniarczyk, S.M, Alba, J.W. The importance of the brand in brand extension. Journal of Marketing Research, 1994; 31 (May):214-28

6. Basu Monga, A., \& Roedder John, D. (2007 March). Cultural differences in brand extension evaluation: The influence of analytic versus holistic thinking. Journal of Consumer Behavior, 33, 529-536.

7. Bhat, S., \& Reddy, S. K. (2001). The impact of parent brand attributes associations and affect on brand extension evaluation. Journal of Business Research, 53, $111-122$

8. Bousch, D. and Loken, B. 1991. A Process Tracing Study of Brand Extensions. Journal of Marketing Research, 28(February), 16-28.

9. Boush, D.M., Shipp, S., Loken, B., Gencturk, E., Crockett, S., Kennedy, E., et al. (1987). Affect generalization to similar and dissimilar brand extensions. Psychology \& Marketing, 225-237.

10. Bottomley, Paul A., and Doyle, John R. 1996. The Formation of Attitudes towards Brand Extensions: Testing and Generalizing Aaker and Keller's Model, International Journal of Research in Marketing, 13, pp. 365- 377. 
11. Bottomley, P. A., \& Holden, S. J. S. (2001). Do we really know how consumers evaluate brand extensions? Empirical generalizations based on secondary analysis of eight studies. Journal of Marketing Research, 38, pp. 494-500.

12. Chen Kuang-Jung, Liu Chu-Mei. Positive brand extension trial and choice of parent brand. Journal of Brand Management, 2004; 13(1):25-36.

13. Czinkota, M. \& Ronkainen, M., 2001. International Business (6th Ed.). Fort Worth: Harcourt College

14. Dacin, P.A., and Smith, D.C. 1997. The Effects of Brand Portfolio Characteristics and Consumer Evaluation of Brands Extensions. Journal of Marketing Research, 31(May), 229-242.

15. De Pelsmacker Patrick, Geuens Maggie, Van den Bergh Joeri. Marketing communications. London: Pitman; 2007

16. Diamantopoulos, A., Smith, G. and Grime, I. (2005), "The impact of brand extensions on brand personality: experimental evidence", European Journal of Marketing, Vol. 39 Nos 1/2, pp. 129-49

17. Erdem, T.1998. An Empirical Analysis of Umbrella Branding, Journal of Marketing Research Vol. XXXV (Aug), 339-351

18. Fiske Susan, T., Pavelchak Mark, A..., Category-based versus piecemeal-based affective responses: developments in schema-triggered affect. In: Sorrentino Richard M, Higgins E. Tory, editors. The handbook of motivation and cognition. Foundations of social behavior. New York: Guilford; 1986. p. 167203.

19. Fombrun, C. and Van Riel, C. 1997. The Reputation Landscape. Corporate Reputation Review, 1 (No. 1 and 2), pp. 5-13.

20. Hakkyun Kim., and Deborah Roedder, John. (2008). Consumer response to brand extensions: Construal level as a moderator of the importance of perceived fit. Journal of Consumer Psychology, 18, 116-126.

21. Herr, P. M., Farquar, P. H., \& Fazio, R. H. (1996). Impact of dominance and relatedness on brand extensions. Journal of Consumer Psychology, 5, 135-159.

22. Kapoor, H. Competitive Effects on the Evaluation of Brand Extension. Ph.d Thesis, Eric Sprott School of Business, Carleton University, Ottawa Ontario.

23. Keller, K. L., 1993. Conceptualizing, Measuring, and Managing Customer-Based Brand Equity. Journal of Marketing, 29 (January), 1-22.

24. Keller, K. L., and Aaker D. A., 1992. The Effects of Sequential Introduction of Brand Extensions. Journal of Marketing Research, 29(1), 35-50.

25. Keller K.L., and Sood Sanjay. Brand equity dilution. MIT Sloan Management Review, 2003; 45(1):12-5.

26. Klink, R. R., \& Smith, D. C. (2001). Threats to the external validity of brand extension research. Journal of Marketing Research, 38(3), 326-335.

27. Kotler, P. and Gary A., 1990. An Introduction to Marketing 2nd ed. Englewood, NJ, Prentice-Hall, Inc.

28. Kotler, P. and Keller, K.L., 1996. Marketing Management, 12th India: Dorling Kindersley (India) Pvt. Ltd.

29. Loken, B. and Deborah J. R., 1993. Diluting Brand Beliefs: When Do Brand Extensions Have a Negative Impact? Journal of Marketing, 57 (July), pp. 71-84.

30. Lye Ashley, Venkateswarlu, P., \& Barrett, Jo. Brand extensions: prestige brand effects. Australasia Marketing Journal, 2001; 9(2):53-65.

31. Lynch, J. G. and Thomas K. S. 1., 1982. Memory and Intentional Factors in Consumer Choice: Concepts and Research Methods. Journal of Consumer Research, 9(June), 18-37.

32. MacInnis, D.J. and Nakamoto, K. Examining factors that influence the perceived goodness of brand extensions. Working Paper, University of Arizona, 1991

33. Monga, A. and Houston, M.J. (2002), "The brand extension evaluation process: insights from the continuum model of impression formation", Advances in Consumer Research, Vol. 29, pp. 188-9.

34. Martinez, E. and de Chernatony, L. (2004), "The effect of brand extension strategies upon brand image", The Journal of Consumer Marketing, Vol. 21 No. 1, pp. 39-50

35. Martínez Eva, Montaner Teresa, and Pina José, M. Brand extension feedback: the role of advertising. Journal of Business Research, 2009; 62(3):305-13

36. Nadim Jahangir, Noorjahan Parvez, Dhrubanil Bhattacharjee, Khondaker Khaled Bin Ahamed (2009). The Relationship between Brand Affect, Brand Quality \& Customers' Brand Extension Attitude: Exploring The Mediating Role Of Customer Loyalty. The Cambodian Management Journal, Vol. 1, No. 1, 20-34.

37. Nan Xiaoli, L. Affective cues and brand-extension evaluation: exploring the influence of attitude toward the parent brand and attitude toward the extension ad. Psychol Market 2006; 23(7):597-616 
38. Nilson, H.T., 1998. Competitive Branding-Winning the Marketplace with Value Added Brands. Chichester: Wiley, cop

39. Nunnally, J., 1978. Psychometric Theory. McGraw-Hill Book Company, New York.

40. Ourusoff, A., Ozanian, M., Brown, P.B. and Starr, J. (1992), "What's in a name? What the world's top brands are worth", Financial World, Vol. 1, September, pp. 32-49.

41. Park, C. W., Millberg, S. \& Lawson, R., 1991. Evaluation of Brand Extensions: The role of Product Level Similarity and Brand Concept Consistency. Journal of Consumer Research, 18 (September).

42. Park, C. W., Milberg, S., \& Lawson, R. (1991). Evaluation of brand extensions: The role of product-level similarity and brand concept consistency. Journal of Consumer Research, 18 (2), 185-193.

43. Park Jong-Won, Kim Kyeong-Heui, and Kim Jung Keun. Acceptance of brand extensions: interactive influences of product category similarity, typicality of claimed benefits, and brand relationship quality. Advance Consumer Research 2002; 29(1):190-8.

44. Pitta, A., and Katsanis, P.L. 1995. Understanding Branding Equity for Successful Brand Extension. Journal of Consumer Marketing, 12(14), 51-64

45. Ries, A., and J. Trout, 1986. Positioning: The battle for your mind. New York: McGraw-Hill.

46. Sandor, Czellar. (2002) Consumer Attitude towards Brand Extensions: An Integrative Model and Research Propositions. University of Geneva, Section HEC, Switzerland

47. Sheinin Daniel, A. The effects of experience with brand extensions on parent brand knowledge. Journal of Business Research, 2000; 49(1):47-55

48. Smith, D. C. and Park, C. W. (1992). The Effects of Brand Extensions on Market Share and Advertising Efficiency. Journal of Marketing Research, 29, pp. 296-313.

49. Smith, E.E., and Medin, D.L., Categories and Concepts. Cambridge, MA: Harvard University Press, 1981

50. Swaminathan, V., Fox, R.J. and Reddy, S.K. (2001), "The impact of brand extension introduction on choice", Journal of Marketing, Vol. 65 No. 4, pp. 1-15.

51. Swaminathan Vanitha. Sequential brand extensions and brand choice behavior. Journal of Business Research 2003; 56(6):431-42.

52. Tait Bruce. Do gaps in marketing theory make new brands fail? Admap 2001(418):40-3 June 2001.

53. Tariq Jalees \& Dr. Tahir Ali. 'How Do Consumers Evaluate Brand Extensions: A five factor approach Market Forces, 2008; 3(4): 09-15.

54. Tauber, E.M. Brand franchise extensions: New products benefit from existing brand names. Business Horizon 1988; 24(2):36 - 41.

55. Van Riel, A.C.R., Lemmink, J. and Ouwersloot, H. (2001), "Consumer evaluations of service brand extensions", Journal of Service Research, Vol. 3 No. 3, pp. 220-31.

56. Völckner Franziska and Sattler Henrik. Drivers of brand extension success. Journal of Marketing 2006; 70 (2):18-34.

57. Völckner, F., H. Sattler, "Empirical Generalizability of Consumer Evaluations of Brand Extensions", May, 2005.

58. Franziska and Sattler Henrik. Drivers of brand extension success. Journal of Marketing 2006; 70 (2):18-34.

59. Wernerfelt, B. R (1988), .Umbrella branding as a Signal of New Product Quality: An Example of Signaling by Posting a Bond. Brand Journal of Economics, 19 (autumn), pp. 458-466. 